\title{
Dinamika keberfungsian dosen penasehat akademik bagi mahasiswa
}

\author{
Nurochim Nurochim ${ }^{*}$ \\ Universitas Islam Negeri Syarif Hidayatullah Jakarta, Indonesia
}

\begin{tabular}{l} 
Article Info \\
\hline Article history: \\
Received Jan $03^{\text {rd }}, 2021$ \\
Revised Feb $18^{\text {th }}, 2021$ \\
Accepted Mar $03^{\text {rd }}, 2021$ \\
\hline
\end{tabular}

\section{Keyword:}

Penasehat akademik

Mahasiswa

Mutu

Layanan kemahasiswaan

\section{Corresponding Author:}

Nurochim Nurochim, Universitas Islam Negeri Syarif Hidayatullah Jakarta

Email: nurochim@uinjkt.ac.id

\begin{abstract}
This study seeks to identify the dynamics of the role of academic advisors in universities. Review literature in the form of articles published in reputable national and international journals. The results of the study show that academic advisors have an important role for students and universities. For students, academic advisors as mentors, discussion partners, related to selfdevelopment that is useful for the future. For universities, academic advisors are a means of providing structured and academic counseling services to consumers, in this case students university. Academic advisors act as a mediator between the empirical situation and the learning process at the university. Academic advisors in an effort to maximize educational services.
\end{abstract}

(C) 2021 The Authors. Published by IICET.

This is an open access article under the CC BY-NC-SA license

(https://creativecommons.org/licenses/by-nc-sa/4.0

\section{Pendahuluan}

Mahasiswa sebagai kelompok peserta didik pada satuan pendidikan tinggi, yang memiliki peran mewujudkan tujuan nasional (Wulan \& Abdullah, 2014). Lebih lanjut Wulan dan Abdulah (2014) mengungkapkan bahwa mahasiswa memiliki kebiasaan menunda penyelesaian skripsi, di mana skripsi sebagai salah satu syarat kelulusan. Selain permasalahan tersebut, keterlambatan studi yang terlihat dari mahasiswa menyelesaikan studi lebih dari 10 semester juga menjadi persoalan yang dihadapi oleh mahasiswa. Hal tersebut disebabkan oleh mahasiswa yang belum beradaptasi dengan cepat dengan budaya akademik di perguruan tinggi, tugastugas akademik yang dianggap sebagai masalah yang berat dibandingan ketika berada pada jenjang sekolah menengah (Raharjo, 2014). Terkait dengan akreditasi lembaga pendidikan tinggi, persoalan mahasiswa yang tidak lulus atau lulus tidak tepat waktu menjadi tolok ukut mutu (Saifudin, 2018). Oleh sebab itu pendampingan dan konseling mahasiswa menjadi layanan esensial, salah satunya melaui layanan perwalian akademik atau pembimbingan akademik.

Penasehat akademik, sebagai layanan yang disediakan untuk mahasiswa berfungsi sebagai sarana memperkuat partisipasi, pemeliharaan, dan kesuksesan akademik mahasiswa. Selain itu penasehat akademik berfungsi untuk sarana integrasi sosial dalam kehidupan kampus (Fussy, 2018). Lebih lanjut bagi Fussy, perwalian akademik sebagai interaksi institusional (penasehat profesional, dosen) dengan mahasiswa yang bertujuan memberikan fasilitas kepada mahasiswa untuk memahami, mengembangkan, realisasi personal, pendidikan, pilihan karir yang lebih baik, serta membimbing mahasiswa memanfaatkan sumber daya universitas dengan maksimal (Fussy, 2018). Penasehat akademik membimbing mahasiswa untuk memiliki 
bidang studi atau mata kuliah atau kursus yang sesuai, hasil belajar utama yang diharapkan, penggunaan sumber pembelajaran di universitas dengan efektif dan bijak, termasuk memenuhi persyaratan akademik lain untuk meningkatkan prestasi akademik dan keep one on track untuk lulus kuliah. Perwalian akademik menjadi elemen esensial dalam institusi pendidikan tinggi yang berkaitan dengan tantangan akademik dan kesuksesan mahasiswa dalam akademik dan profesionalnya di masa yang akan datang.

Unsur keteladanan dalam perwalian akademik menjadi penting, sebab wali akademik memiliki peran dan fungsi sebagai model. Keteladanana yang dimaksud adalah memberikan contoh kepada mahasiswa akan sebuah profesionalitas dan insan bermoral pancasila (Mulyadi, 2002). Berdasarkan pancasila, tindakan berpedoman pada hubungan dengan Tuhan dan hubungan dengan sesama manusia. Lebih lanjut Mulyadi mengungkapkan bahwa peran dan fungsi dosen PA belum terlaksana dengan baik (Mulyadi, 2002). Sehingga Mulyadi menyarankan adanya sistem pengawasan terhadap keberfungsian penasehat akademik.

Elemen perwalian akademik mahasiswa sebagai salah satu upaya untuk memenuhi cakupan kinerja utama perguruan tinggi. Sasaran kinerja perguruan tinggi adalah meningkatnya kualitas lulusan pendidikan tinggi, yang ditunjukkan dengan lulusan yang dengan pendapatan lebih dari UMR (Upah Minimum Regional), dalam masa tunggu kurang dari 6 bulan. Selain itu lulusan dapat melanjutkan pendidikan ke jenjang lebih lanjut dalam jangka waktu kurang dari 12 bulan setelah lulus (Mendikbud, 2020, Indikator Kinerja Perguruan Tinggi). Sedangkan berbagai persyaratan personal diutamakan oleh pemberi kerja, seperti kemampuan berpikir sistematis hingga keterampilan yang berkaitan dengan bidang kerja atau keterampilan berbahasa asing, untuk bersinergi dan mengikuti perkembangan zaman. Selain hard skill pihak pemberi kerja mempersyaratkan unsur soft skill seperti komunikasi dan hubungan interpersonal yang baik. Sebagaimana tertera dalam info penawaran lowongan magang berikut ini:

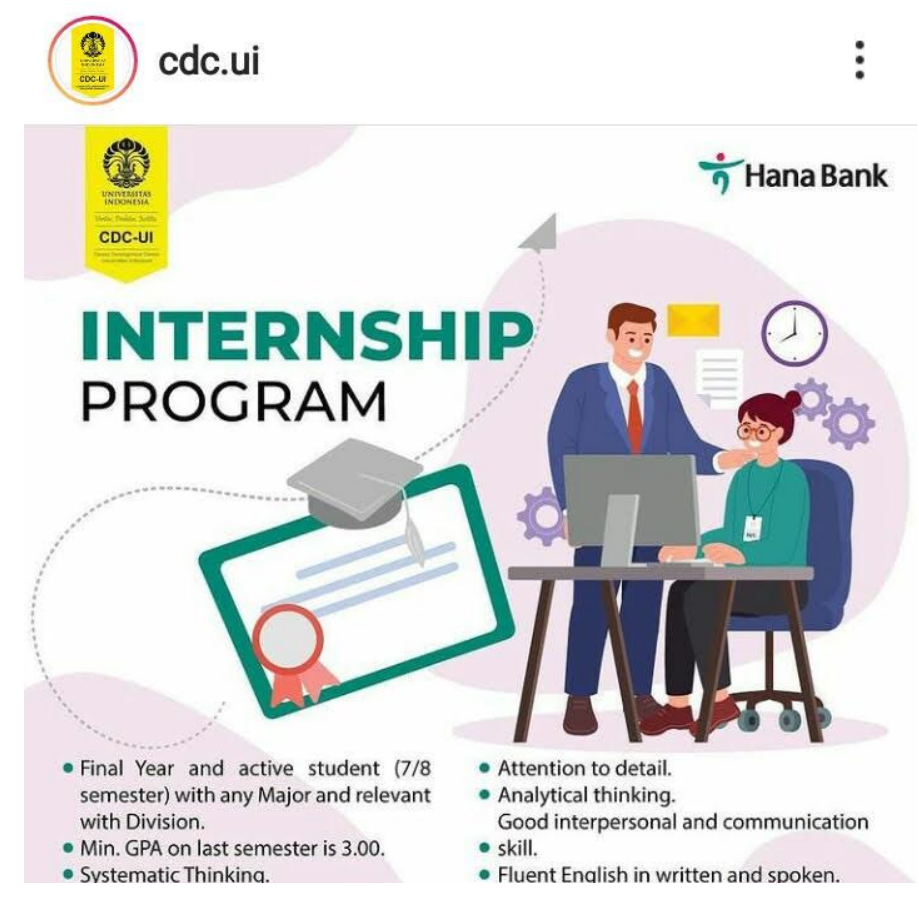

Gambar 1. Penawaran Program Magang, Gambar Diambil Dari Instagram CDC Universitas Indonesia, 2020

Penasehat akademik sebagai bagian yang tidak terpisahkan dengan sebuah perguruan tinggi. Di mana perguruan tinggi sebagai pusat penyelenggaraan dan pembinaan ilmu pengetahuan, sehingga diperlukan berbagai unit pendukung, salah satunya adalah dosen penasehat akademik. Pentingnya dosen penasehat akademik, terlihat dari persetujuan rencana studi mahasiswa oleh dosen PA. Selain itu perguruan tinggi senantiasa menyusun pedoman panduan penasehat akademik, dan mewajiban mahasiswa berkonsultasi dan berdiskusi dengan dosen PA minimal 3 kali setiap semester (Fakultas Kesehatan Masyarakat Universitas Andalas, 2014). Ditambah dengan acuan berupa SOP mengenai pelaksanaan perwalian (Universitas Islam Negeri Walisongo Semarang, 2016). Berdasarkan SOP, perwalian akademik diharapkan memenuhi kelengkapan institusi, dan ketenagaan yang memiliki kompetensi dan komitmen konseling (Khairun \& Hakim, 2018). Mengingat pentingnya penasehat akademik, beberapa perguruan tinggi menyusun jadwal pertemuan rutin antara dosen PA dan mahasiswa. 


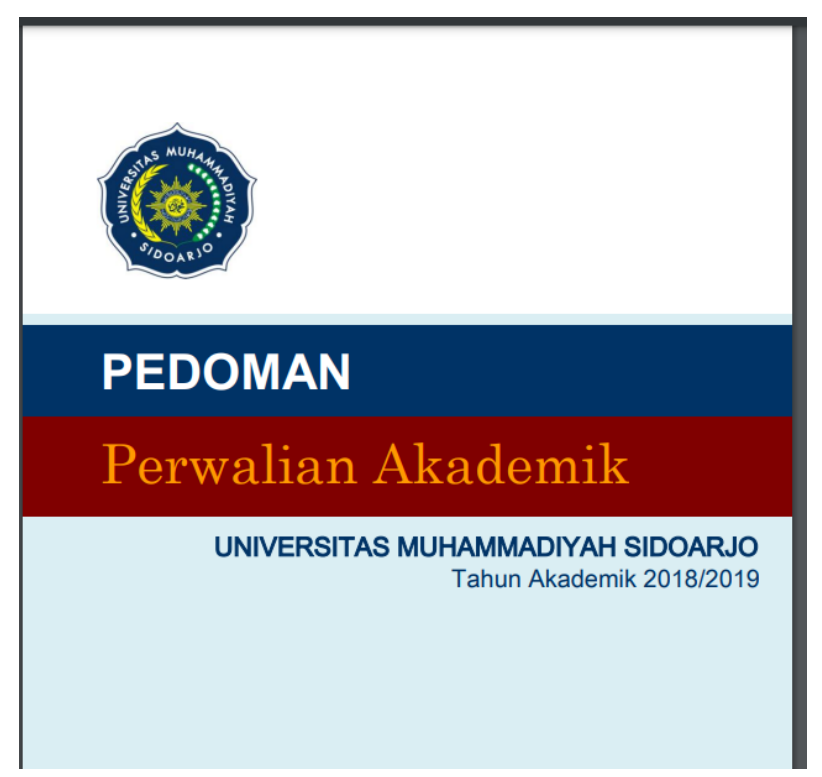

Gambar 2. Pedoman Perwalian Akademik Universitas Muhammadiyah Sidoarjo Tahun Akademik $2018 / 2019$

Hal tersebut menunjukkan bahwa perwalian akademik sebagai kegiatan yang penting dalam lingkup layanan pendidikan tinggi. Penasehat akademik dibutuhkan untuk mendampingi mahasiswa agar optimal menyelesaikan studinya, membimbing persiapan karir, dan menyesuaikan diri secara positif (Tambusai, 2018). Dosen penasehat akademik sebagai unsur penting perguruan tinggi, terdapat permasalahan dalam pelaksanannya diantaranya adalah kurangnya waktu konseling sehingga belum sekalipun memberikan bimbingan akademik, respek dosen yang kurang dan sering emosional, mahasiswa kurang mendapatkan pembimbingan skripsi dan cara meneliti yang baik (Saputra, Yusuf, \& Syahniar, 2013). Ditambah dengan dari sisi mahasiswa yang tidak disiplin mengikuti jadwal bimbingan akademik yang sudah disusun oleh bidang akademik dan kemahasiswaan (Fakhruddin \& Safrianti, 2017).

Selain itu berdasarkan kajian dari Indonesia menunjukkan bahwa, penasehat akademik (PA) dipandang tidak memiliki hubungan dengan masalah akademik mahasiswa (Saputra et al., 2013). Kinerja dosen PA yang sejauh ini masih sebagai tugas tambahan, sehingga menimbulkan polarisasi pentingnya dosen PA, bahkan dosen yang bersangkutan belum memiliki kesadaran akan pentingnya bimbingan dan konseling bagi mahasiswa dan dampaknya terhadap lembaga. Permasalahan mengenai kinerja dosen PA adalah tugas dan fungsi yang berkaitan dengan pendidikan dan pengajaran, penelitian, dan pengabdian masyarakat. Ditambah dengan banyaknya jumlah mahasiswa yang tidak sebanding dengan jumlah dosen PA (Susilowati, 2008). Sebab untuk menjadi konselor perlu memperhatikan berbagai hal seperti memahami budaya akademik universitas termasuk sarana dan prasarana dan penggunaannya. Terkait dengan sarana dan prasaran konseling juga menjadi faktor penghambat, seperti ruang konseling yang memungkinkan adanya rasa aman dalam mengemukakan keluhan (Mbira, 2013). Hal tersebut ditambah dengan era digital dan globalisasi yang melingkupi perilaku masa kini dan masa depan. Oleh sebab itu penting dikaji dinamika peran dosen penasehat akademik bagi mahasiswa.

\section{Metode}

Kajian ini merupakan telaah literatur terstruktur. Upaya penelitian ini untuk mengidentifikasi topik perwalian akademik sebagai layanan mahasiswa. Selain itu unsur kelembagaan yang melingkupi kondisi exsisting perwalian akademik. Elemen kelembagaan tersebut berupa kebijakan, dukungan dana, pendidikan dan pelatihan berkelanjutan, sosialisasi, maupun penelitian dan pengembangan terkait program perwalian akademik, serta inovasi lembaga pendidikan tinggi dalam pemanfaatan program PA. Literatur yang dikaji berupa naskah artikel yang dipublikasikan pada jurnal bereputasi internasional dan nasionalnya. Selain itu kebijakan-kebijakan tingkat lembaga pendidikan tinggi seperti standard operational procedure terkait tugas pokok dan fungsi dosen penasehat akademik. 


\section{Hasil dan Pembahasan}

Mahasiswa memiliki tingkat stress pada tingkat tertentu, sebagai dampak perubahan kebiasaan pendidikan sekolah menengah dan universitas, selain itu kondisi sebagian mahasiswa yang membiayai kehidupan secara mandiri, ketidakmampuan untuk mengelola stress, tekanan mental, dan beban kerja yang bertambah. Tidak hanya kondisi psikologis, mahasiswa juga mengalami gangguan kesehatan fisik mulai yang ringan hingga berat seperti jantung koroner dan asam lambung kronis. Apapun kondisinya, mahasiswa diharapkan mampu untuk menyelesaikan studinya, sebab kredensial pendidikan tinggi tetap menjadi persyaratan dalam pasar kerja dengan gaji tinggi. Selain itu kelulusan mahasiswa sebagai tolok ukur mutu layanan sebuah universitas atau lembaga pendidikan. Sehingga dipahami bahwa kelulusan mahasiswa dipandang penting bagi pasar (pasar tenaga kerja, pasar wirausaha), dan konsumen (mahasiswa). Mahasiswa yang lulus dibedakan menjadi kelompok lulusan dengan kriteria tertentu seperti lulus tepat waktu, lulus dengan indeks prestasi akademik yang tinggi, ataupun lulus dengan prestasi yang berkaitan dengan pendidikan dan pelatihan. Secara demografispun, mahasiswa memiliki latar belakang yang berbeda-beda, gender, etnis, dan motivasi. Secara personal, mahasiswa bermasalah dengan pembagian waktu dan prioritas kegiatan, pemahaman keilmuan yang holistik sehingga berdampak pada penyelesaian skripsi (Etika \& Hasibuan, 2016). Hal tersebut menjadi faktor penting adanya peran dosen penasehat akademik.

Lembaga pendidikan tinggi secara formal terdeferensiasi sebagai universitas, politeknik, institute, sekolah tinggi, akademi, dan akademi komunitas (Croxford \& Raffe, 2015; Undang-Undang Pendidikan Tinggi Republik Indonesia, 2012). Lebih lanjut Croxford \& Raffe (2015) mengungkapkan bahwa herarki pendidikan tinggi berbentuk vertikal dan horizontal, status lembaga dan kapasitas berupaya menarik calon siswa dengan kualifikasi unggul dan status yang tinggi sebagai dimensi vertikal. Berbagai jenis pendidikan tinggi tersebut tidak lepas dari tujuan dan sasaran layanannya dalam mengelola sumber daya mahasiswa. Menanggapi perluasan sistem, bahwa mahasiswa yang lulus penting dipastikan siap masuk dalam pasar tenaga kerja, memiliki keterampilan teknis dan kognitif, serta memiliki perilaku dan sikap sosial yang tepat (Kementerian Pendidikan Dan Kebudayaan, 2014). Lembaga pendidikan tinggi sebagai salah satu sarana mobilitas sosial, dengan cara mempertaruhkan berbagai modal tertentu seperti ekonomi, waktu, pengetahuan untuk mendapatkan berbagai modal lain untuk memperkuat posisi sosial di masa yang akan datang (Bathmaker, Ingram, \& Waller, 2013). Perguruan tinggi seperti berada dalam arena petarungan untuk mewujudkan lulusan yang paling berbakat dan meningkatnya pengakuan pasar tenaga kerja terhadap lulusannya. Hal tersebut sebagai harapan bahwa menjadi mahasiswa adalah mempersiapkan dirinya untuk pekerjaan di masa depan. Tentunya dengan realitas yang berbeda dengan yang diharapkan, berbagai tantangan muncul seperti perbedaan minat kajian dan metodologi penelitian dengan dosen, serta perbedaan budaya dan kondisi demografis di perguruan tinggi. Sebagaimana diungkap Rowlands (2018) bahwa universitas sebagai wadah pengembangan modal intelektual.

Perwalian akademik dalam kerangka layanan konsumen tercakup dalam keilmuan manajemen pendidikan, administrasi pendidikan, kajian pendidikan tinggi, dan kebijakan publik. Dalam kerangka kebijakan publik, institusi pendidikan tinggi sebagai produsen dengan berbagai macam keahlian dan pengetahuan. Kampus menyediakan pengajaran kepada siswa dengan berbagai latar belakang budaya, status sosial ekonomi, dan keahlian. Dengan demikian, kampus mengupayakan input, proses, dan output yang berbasis pada konsumen, khususnya mahasiswa (Johnes \& Ruggiero, 2017). Kampus sebagai sarana transfer of knowledge diperlukan elemen yang komprehensif dan saling mendukung, di sini peran wali akademik sebagai aktor penting sebagai mediator segala sumber daya. Kampus sebagai pemberi layanan pembelajaran yang bermakna, berupaya untuk penguatan kesiswaan, kewargaan global, menusia berpengetahuan dan berketerampilan (Bennett, Sunderland, Bartleet, \& Power, 2016). Sebagai contoh di Universitas Marymount, Amerika Serikat, perwalian akademik sebagai sebuah tim atau panitia yang saling bekerja sama dengan unit akademik (Schaeffer \& Rouse, 2013). Perwalian akademik atau penasehat akademik sebagai upaya untuk meningkatkan akuntabilitas pembelajaran.

Kepemilikan sarana seperti buku pedoman pembimbingan, pemahaman prinsip dasar dan mekanisme bimbingan, dan psikologi dan teori pembelajaran yang memadai menjadi faktor keterlaksanaan pembimbingan akademik (Ilyas, 2008). Lebih lanjut Ilyas (2008) mengungkapkan bahwa pembimbing akademik melaksanakan peran dan fungsi sebagai organisator, fasilitator, inovator, teladan, evaluator, pembimbing, kreator, pengabdi dan pelayanan masyarakat, dan konselor. Pendampingan akademik berbasis siswa sehingga penting mengacu pada teori dan pengembangan pembelajaran (Jayne K. Drake, Peggy Jordan, Marsha A. Miller, Alexander W. Astin, \& Helen S. Astin, 2013). Hal tersebut ditambah dengan pemenuhan tugas utama dosen sebagai aktor transformasi dan pengembangan ilmu pengetahuan, teknologi, dan seni melalui lembaga pendidikan tinggi (Peraturan Pemerintah Republik Indonesia Nomor 37 Tahun 2009). 
Artinya, dosen berbekal pengetahuan dan keterampilan psikologis dan pedagogis. Dalam peran tersebut dibutuhkan berbagai dukungan bahan dan alat serta pengembangan kapasistas perorangan secara kelembagaan.

Perwalian akademik vakum tanpa dukungan rumusan tujuan pendampingan, strategi, berbagi pengalaman positif, dan kesempatan untuk merefleksikan serta membandingkan hasil konseling, jika terdapat permasalahan yang sama dengan sesame dosen pernasehat akademik untuk evaluasi. Pembinaan akademik berpusat pada mahasiswa tidak bersifat top-down atau bottom-up, namun saling menghormati, dan kombinasi yang dinamis, baik konselor individual, unit, dan kelembagaan secara keseluruhan. Lembaga menyusun seperangkat tujuan yang akan dicapai, tindakan pendampingan, dan memperkuat pengalaman mahasiswa. Pembimbingan akademik mempersyaratkan komunikasi rutin, dukungan emosional selama proses konseling. Pembimbingan akademik juga dapat digunakan sebagai sarana menanggulangi plagiarism dan pelanggaran akademik lainnya seperti memcontek, fabrikasi, dan pemalsuan data (Patrzek, Sattler, van Veen, Grunschel, \& Fries, 2015).

Perwalian akademik sebagai upaya administratif seperti pemenuhan dan pemanfaatan big data. Di era digital dan ketidakpastian ini, penasehat akademik dapat menghimpun berbagai data kuantitatif dan kualitatif kemahasiswaan yang berfungsi untuk mengurangi dampak negatif terkait mahasiswa yang putus studi. Pemetaan permasalahan mahasiswa termasuk prestasi akademik, pola perilaku, karakteristik sosioekonomi dan demografi digunakan untuk mengidentifikasikan tinggi rendahnya angka putus studi (Sorensen, 2019). Pembimbingan akademik sebaga sarana membangun relasi baik antara universitas kepada mahasiswa untuk pengembangan mahasiswa secara optimal, dengan semakin mengenal seluk beluk kampus. Hal tersebut sebagai konsep membangun rasa percaya dan yakin melalui kelekatan mahasiswa dan staff (Owens \& Johnson, 2009). Perwalian akademik sebagai kerjasama yang berkelanjutan dalam konsep kepemimpinan. Mahasiswa sebagai kelompok remaja dewasa membutuhkan leading untuk mengembangkan minat dan bakatnya, memantapkan pilihannya berdasarkan pada pertimbangan real, melalui pendampingan akademik inilah leadership ini dapat dicapai (Mitra, 2005).

Penasehat akademik difungsikan secara berbeda pada masing-masing lembaga. Penasehat akademik sebagai tugas utama yang melayanani pembimbingan mahasiswa lintas fakultas yang berbeda pada masingmasing kelompok mahasiswa. Hal tersebut berdampak pada kepuasan terhadap proses layanan pendampingan akademik. Namun demikian perwalian akademik penting menjadi sebuah sistem yang efektif, menjadi aktivitas prioritas pendidikan tinggi, pelatihan bagi advisor, tanggung jawab yang terdefinisikan dan tersosialisasikan dengan jelas, pengembangan materi dan akses yang lebih luas, bertanggung jawab, terukur, dan berdampak pada penghargaan (Lowe \& Toney, 2000). Hal tersebut berdasar pada pembimbingan akademik masih dianggap sebagai aktivitas minor, diangap sebagai kegiatan yang kurang penting dibandingkan kegiatan lain yang sudah terlembagakan dan sistematis, dan pendampingan akademik dilaksanakan tanpa ada koordinasi dan dukungan proses dari seluruh warga kampus.

Pembimbingan akademik dalam kajian pendidikan tinggi, berfungsi untuk mencapai tujuan organisasi. Sebagai contoh perwalian mahasiswa dengan bentuk bimbingan akademik dan rohani serta karakter, terwujud dengan bimbingan rencana strudi, doa bersama, konseling personal, dan pendalaman kajian KeTuhanan (Darmawan \& Triastanti, 2020). Hal tersebut dikaitkan dengan kegiatan ekstrakurikuler yang mendukung bakat dan minat mahasiswa untuk memperkuat pengalaman diri di dalam kampus. Penasehat akademik membantu mahasiswa untuk mencapai indeks prestasi terbaik yang dipahami sebagai ukuran kesuksesan akademik (Young • Jones, Burt, Dixon, \& Hawthorne, 2013). Penasehat akademik profesional bekerja secara kekeluargaan sehingga memungkinkan adanya keadilan sosial, kesehataan, dan inklusif (Kathleen \& Worrell, 2019). Berdasar pada kondisi bahwa pembelajaran diperguruan tinggi terdapat perbedaan latar belakang pengalaman dan gaya belajar.

Permasalahan keberfungsian perwalian akademik adalah mahasiswa yang belum mengenal dosen PA, sehingga mahasiswa enggan melaksanakan proses pembimbingan, ditambah dengan mahasiswa yang tidak mau berkonsultasi dengan dosen PA tentang permasalahan kuliah, pertemuan dengan dosen PA yang belum terjadwal dengan baik, SOP yang belum tersosialisasi dengan baik kepada pemangku kebijakan, evaluasi dan laporan oleh dosen PA yang belum terstruktur, dosen PA yang belum memahami tugas dan fungsinya secara komprehensif tentang tugasnya (Febriyarni, 2018). Meskipun tidak semua karakteristik siswa memiliki relevansi dengan pendampingan akademik, namun terdapat hubungan yang positif antara pendekatan holistik untuk pendampingan akadmik terhadap kepuasan pendampingan (Coll, 2008). Oleh sebab itu pendampingan akademik mempengaruhi sudut pandang mahasiswa. Pendampingan akademik sebagai sarana bertukar informasi dengan mahasiswa. Pendampingan akademik yang holistik tidak hanya berkaitan dengan kurikulum dan kelembagaan namun juga teori pengembangan kemahasiswaan, gaya belajar, keterampilan kognitif, dan perbedaan budaya. Peran penasehat akademik menjadi lebih kompleks sebab 
menyesuaikan kebutuhan mahasiswa yang tidak hanya bervariasi dari segi latar belakang budaya namun juga perbedaan usia dan gender, dan juga perbedaan sudut pandang.

\section{Simpulan}

Bimbingan akademik sebagai upaya untuk meningkatkan ketekunan, motivasi, mengurangi hambatan, sebagai sarana informasi, dan sense of belonging siswa, sehingga diharapkan mahasiswa dapat lulus tepat waktu dan memiliki prestasi akademik dan non akademik yang optimal. Pembimbingan akademik dilembagakan dengan rekrutmen advisor, pendidikan dan pelatihan, dana, dukungan kebijakan dan sosialisasi berkelanjutan, para aktor yang memahami pentingnya program pendampingan. Dalam kerangka kebijakan publik, program bimbingan akademik sebagai upaya efektivitas capaian mutu layanan konsumen khususnya mahasiswa. Pendampingan akademik sebagai upaya leading kepada mahasiswa untuk pengembangan diri, melalui analisis data kuantitatif dan kualitatif. Pendampingan akademik sebagai proses pengembangan kemahasiswaan secara holistik. Oleh sebab itu pendampingan akademik penting dibudayakan oleh seluruh administrator dan pembuat kebijakan.

\section{Referensi}

Bathmaker, A. M., Ingram, N., \& Waller, R. (2013). Higher Education, Social Class and The Mobilisation of Capitals: Recognising and Playing the Game. British Journal of Sociology of Education, 34(5-6), 723-743. https://doi.org/10.1080/01425692.2013.816041

Bennett, D., Sunderland, N., Bartleet, B. L., \& Power, A. (2016). Implementing and sustaining higher education service-learning initiatives: Revisiting Young et al.'s organizational tactics. Journal of Experiential Education, 39(2), 145-163. https://doi.org/10.1177/1053825916629987

Coll, J. E. (2008). A Study of Academic Advising Satisfaction and Its Relationship to Student Worldviews. Journal of College Student Retention: Research, Theory and Practice, 10(3), 391-404. https://doi.org/10.2190/CS.10.3.g

Croxford, L., \& Raffe, D. (2015). The Iron Law of Hierarchy? Institutional Differentiation in UK Higher Education. Studies in Higher Education, 40(9), 1625-1640. https://doi.org/10.1080/03075079.2014.899342

Darmawan, I. P. A., \& Triastanti, D. (2020). Pola Perwalian Sebagai Pembinaan Akademik, Kerohanian dan Karakter Mahasiswa. Jurnal Ilmiah Religiosity Entity Humanity (JIREH), 2(1), 13-26. https://doi.org/10.37364/jireh.v2i1.32

Etika, N., \& Hasibuan, W. F. (2016). Deskripsi Masalah Mahasiswa Yang Sedang Menyelesaikan Skripsi. KOPASTA: Jurnal Program Studi Bimbingan Konseling, 3(1), 40-45. https://doi.org/10.33373/kop.v3i1.265

Fakhruddin, \& Safrianti, E. (2017). Pelayanan Penasehat Akademik (PA) Dalam Meningkatkan Prestasi Mahasiswa. Al-Idarah: Jurnal Manajemen Dan Administrasi Islam Pelayanan, 1(1), 105-118.

Fakultas Kesehatan Masyarakat Universitas Andalas. (2014). Panduan Penasehat Akademik Kemahasiswaan (PAK).

Febriyarni, B. (2018). Peran Dosen Penasehat Akademik (PA) Prodi Perbankan Syariah Jurusan Syariah dan Ekonomi Islam STAIN Curup Dalam Menangani Permasalahan Mahasiswa. Islamic Counseling: Jurnal Bimbingan Konseling Islam, 2(2), 133. https://doi.org/10.29240/jbk.v2i2.565

Fussy, D. S. (2018). The Status of Academic Advising in Tanzanian Universities. KEDI Journal of Educational Policy, 15(1), 81-98.

Ilyas. (2008). Peran Ideal Dosen Pembimbing Akademik Dan Prestasi Belajar Mahasiswa. EDUCARE, 6(1), 85-94. Retrieved from http://educare.e-fkipunla.net

Jayne K. Drake, Peggy Jordan, Marsha A. Miller, Alexander W. Astin, \& Helen S. Astin. (2013). Academic Advising Approaches: Strategies That Teach Students to Make the Most of College. Retrieved from https://remote-lib.ui.ac.id:2135/lib/indonesiau-ebooks/detail.action?docID=1343439

Johnes, G., \& Ruggiero, J. (2017). Revenue Efficiency in Higher Education Institutions Under Iperfect

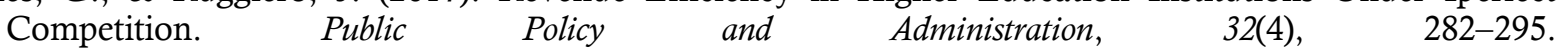
https://doi.org/10.1177/0952076716652935

Kathleen, L., \& Worrell. (2019). Professional Learning and Social Justice: Engaging Academic Advisors in Higher Education.

Kementerian Pendidikan Dan Kebudayaan. (2014). Sistem Pendidikan Tinggi Indonesia: Seberapa Responsif Terhadap Pasar Kerja?

Khairun, D. Y., \& Hakim, I. Al. (2018). Profil Layanan Dosen Pembimbing Akademik. JURNAL EDUKASI: Jurnal Bimbingan Konseling, 4(1), 31-43. https://doi.org/10.22373/je.v4i1.3521

Lowe, A., \& Toney, M. (2000). Academic Advising: Views of the Givers and Takers. Journal of College Student 
Retention: Research, Theory \& Practice, 2(2), 93-108. https://doi.org/10.2190/d5fd-d0p8-n7q2-7dq1

Mbira, H. (2013). Peran Pembimbing Akademik (PA) Pada Era ICT. Jurnal Info Kesehatan, 11(2), 397-405.

Mendikbud. Indikator Kinerja Utama Lembaga Pendidikan Tinggi. , (2020).

Mitra, D. L. (2005). Adults Advising Youth: Leading While Getting Out of the Way. Educational Administration Quarterly, 41(3), 520-553. https://doi.org/10.1177/0013161X04269620

Mulyadi. (2002). Peran Dan Fungsi Dosen Penasehat Akademik.

Owens, M. A., \& Johnson, B. L. (2009). From Calculation Through Courtship to Contribution Cultivating Trust Among Urban Youth in an Academic Intervention Program. Educational Administration Quarterly, 45, 312-347. https://doi.org/10.1177/0013161X08330570

Patrzek, J., Sattler, S., van Veen, F., Grunschel, C., \& Fries, S. (2015). Investigating the Effect of Academic Procrastination on the Frequency and Variety of Academic Misconduct: a Panel Study. Studies in Higher Education, 40(6), 1014-1029. https://doi.org/10.1080/03075079.2013.854765

Peraturan Pemerintah Republik Indonesia Nomor 37 Tahun 2009. Peraturan Pemerintah Republik Indonesia Nomor 37 Tahun 2009 Tentang Dosen. , 4 § (2009).

Raharjo, R. (2014). Problem dan Solusi Studi Mahasiswa Semester Tua. Nadwa, 8(2), 313. https://doi.org/10.21580/nw.2014.8.2.584

Rowlands, J. (2018). Deepening Understandings of Bourdieu's Academic and Intellectual Capital Through a Study of Academic Voice Within Academic Governance. Studies in Higher Education, 43(11), 1823-1836. https://doi.org/10.1080/03075079.2017.1284192

Saifudin, A. (2018). Metode Data Mining Untuk Seleksi Calon Mahasiswa Pada Penerimaan Mahasiswa Baru di Universitas Pamulang. Jurnal Teknologi, 10(1), 25-36.

Saputra, N. A., Yusuf, A. M., \& Syahniar. (2013). Kinerja Dosen Penasehat Akademik dan Hubungannya dengan Masalah Akademik Mahasiswa dalam Perkuliahan Guru. Jurnal Konseling Dan Pendidikan, 1(3), 28. https://doi.org/10.29210/110900

Schaeffer, D. M., \& Rouse, D. (Nick). (2013). Effective Academic Advisory Committee Relationships. Contemporary Issues in Education Research (CIER), 7(1), 23. https://doi.org/10.19030/cier.v7i1.8308

Sorensen, L. C. (2019). "Big Data" in Educational Administration: An Application for Predicting School Dropout Risk. Educational Administration Quarterly, 55(3), 404-446. https://doi.org/10.1177/0013161X18799439

Susilowati, T. (2008). Peran Dosen Pembimbing Akademik (PA) Terhadap Pretasi Belajar Mahasiswa. MIIPS, $8(2), 57-65$.

Tambusai, K. (2018). Kebutuhan Akan Penasehat Akademik di Perguruan Tinggi. Al-Idarah, V(6), 87-99.

Undang-Undang Pendidikan Tinggi Republik Indonesia. Undang-Undang Republik Indonesia Nomor 12 Tahun 2012 tentang Pendidikan Tinggi. , Undang-Undang Pendidikan Tinggi § (2012).

Universitas Islam Negeri Walisongo Semarang. SOP Pelaksanaan Perwalian. , (2016).

Wulan, D. A. N., \& Abdullah, S. M. (2014). Prokrastinasi Akademik Dalam Penyelesaian Skripsi. Sosio Humaniora, 5(1), 1-25. Retrieved from file:///C:/Users/anggirahmas/Downloads/136-379-1-PB.pdf

Young Jones, A. D., Burt, T. D., Dixon, S., \& Hawthorne, M. J. (2013). Academic Advising: Does it Really Impact Student Success? Quality Assurance in Education, 21(1), 7-19. https://doi.org/10.1108/09684881311293034 